\title{
Psycho-Pedagogical and Educational Aspects of Gifted Students, Starting from the Preschool Age; How Can Their Needs Be Best Met?
}

\section{Dimitrios Papadopoulos*}

Department of Psychology, South-West University "Neofit Rilski”, Blagoevgrad, Bulgaria

\begin{abstract}
Giftedness responds in people from infancy through adulthood. Although research has recognised the early years in a gifted child's future development and learning as critical, preschool teachers and school psychologists of this population have limited knowledge about the expression and special characteristics of giftedness at this stage of development.

Due to the fact that gifted children have special learning and cognitive abilities, it is important for teachers to recognize these characteristics at an early stage, and then design and implement gifted intervention programs. Additionally, the enrollment of gifted children in conventional classrooms that do not follow any kind of gifted educational program as for the teaching style, pose risk factors for inhibiting the development of their talents and the experience of positive emotions. Further, many gifted children exhibit even from preschool age feelings of frustration, boredom, low self-esteem, under-achievement and other negative characteristics, that may be the result of their asynchronous development or are due to the inability of school to identify their special abilities and support them with gifted pedagogical methods.
\end{abstract}

Keywords: Gifted children; Preschool gifted education; Learning and cognitive abilities; Psycho-pedagogical characteristics

\section{Introduction}

The preschool period has been described as one of the major challenges and changes of young children development [1]. Children develop cognitively, linguistically, emotionally and socially. Their development is characterized by large and growth advance including thinking, planning and mathematical skills. These skills are used to solve problems and contribute to new learning, allowing children to become "independent learners" [2].

Many young children, who are thought to be developing, are typically found to develop and learn quickly, and their achievements are the results of a combination of high intellectual-cognitive ability, motivation, creative thinking and environmental factors. These students who show exceptionally high potential ability are described as gifted [3]. The percentage of gifted children accounts for about $3 \%$ to $10 \%$ in the general child population depending on the identification method [4]. Educators and school psychologists recognize the special needs of this group and the benefits of early identification and intervention, but many early childhood programs are not equipped to meet the needs of young students with intellectual abilities or special talents. Gifted children even at preschool age exhibit specific cognitive, learning and educational characteristics that teachers and parents should recognize carefully. If not treated promptly, then the development of educational and psychosocial difficulties in the future is at risk $[5,6]$.

\section{Notion of Giftedness}

Intelligence, creativity and talent are central concepts and are included in the various definitions that have been proposed for giftedness [7]. Different definitions of giftedness have evolved from a single intellectual performance [8] to the identification of multiple abilities and intelligences [9-13]. Multifaceted approaches such as those of Gardner [13], Sternberg [12] and Renzulli [11] are consistent with present theory and research. Sternberg first introduced his enriched triad theory of intelligence in 1984 with the categories of analytical, creative, and practical intelligence. Both Gardner's theory of multiple intelligences and the three-ring Renzulli's model of gifted behaviour serve as precise examples of multifaceted and well-researched theories of intelligence and giftedness [14]. According to the National Association for Gifted Children [15] giftedness is defined as a developmental process with special cognitive, behavioural, and neuropsychological benchmarks.

The most commonly used definition of giftedness proposed by Marland [10], has been adopted by the US Department of Education.

"Gifted and talented children are those identified by professionally qualified persons who by virtue of outstanding abilities are capable of high performance. These are children who require differentiated educational programs and/or services beyond those normally provided by the regular school program in order to realize their contribution to self and society. Children capable of high performance include those with demonstrated achievement and/ or potential ability in any of the following areas, singly or in combination: general intellectual ability; specific academic aptitude; creative or productive thinking; leadership ability; visual and performing arts; psychomotor ability" [16]

Later definitions of gifted and talented children evolved to include the social and emotional aspects of being gifted. In 1991, the Columbus Group, a group of educators, parents, and psychologists, recommended a definition of giftedness. This definition of giftedness focuses on the cognitive and emotional characteristics of the individual [17].

"Giftedness is asynchronous development in which advanced cognitive abilities and heightened intensity combine to create inner experiences and awareness that are qualitatively different from the norm. This asynchrony increases with higher intellectual capacity. The uniqueness of the gifted renders them particularly vulnerable and requires modifications in

*Corresponding author: Dimitrios Papadopoulos, Ph.D., M.Sc. in Soc. Psychiatry - Child Psychiatry, Department of Psychology, South-West University "Neofit Rilski”, Blagoevgrad, Bulgaria, Tel: +359 73885 501; E-mail: d.papadopoulos@ swu.bg

Received August 08, 2016; Accepted August 26, 2016; Published September 02, 2016

Citation: Papadopoulos D (2016) Psycho-Pedagogical and Educational Aspects of Gifted Students, Starting from the Preschool Age; How Can Their Needs Be Best Met? J Psychol Abnorm 5: 153. doi: 10.4172/2471-9900.1000153

Copyright: ( 2016 Papadopoulos D. This is an open-access article distributed under the terms of the Creative Commons Attribution License, which permits unrestricted use, distribution, and reproduction in any medium, provided the original author and source are credited. 
parenting, teaching and counselling in order for them to develop optimally. [18]."

Recent research has suggested that a high level of intelligence, coupled with high levels of creativity, and together with other factors such as personality traits, motivation and environmental factors make up what is called giftedness [19]. However, there is lack of consensus concerning the concept of giftedness [20], the characteristics of the gifted individual, how it develops, etc. [21]. Research on giftedness is diverse. There are many distinct definitions of giftedness, and as mentioned above, so far only little consensus has been reached.

\section{Identification and Diagnosis}

Identification of gifted children at kindergarten and first grades of elementary is important for their talents and ability development [22]. At the beginning of the 20th century and for many years to follow, the recognition of gifted and talented children was based exclusively on the IQ tests. Over the last decades, although school psychologists use multiple criteria for evaluating gifted children, a global IQ score is still the dominant criterion for identification and acceptance into gifted programs at school $[23,24]$. Thus a child is identified as "gifted" if his or her IQ has proved to be exceptionally high on the basis of an attentive assessment conducted by a school psychologist. It's still relatively usual that a child with an IQ of 115 or more (10\% of the student population) is identified as mildly gifted, talented or high ability child and a child with an IQ of 125 and greater (2,5\%-5\% of the student population) is identified as typically gifted [7]. Traditional methods of identifying gifted children are intelligence tests, achievement tests, aptitude tests and school grades [25]. Although intelligence test scores are most often recognised and accepted, other non-traditional identification tools may also be employed [26]. However, in many cases, parents have identified their children as gifted long before any formal identification takes place [27].

\section{Cognitive, Learning and Educational Characteristics of Gifted Children}

The development of gifted children through the developmental stages follows the same course with that of children of typical development. However, it is characterized by early development of higher linguistic, cognitive functions and psychomotor abilities. Research suggests that needs and problems arise more often among children of higher intelligence [28]. Even though we have an adequate knowledge about cognitive development and the learning abilities of average intelligent students, the same does not apply for gifted children.

Hints of giftedness often become evident during the early development of the child, even from infancy or early childhood. Early speaking, walking or reading may constitute indicators of an overall premature development [29]. Gifted children from early childhood and preschool period exhibit massive amounts of energy, fair memory, rich vocabulary, strong imagination, remarkable use of objects, great interest to meet their environment. They also accept the help of others and have a strong desire to discover, to try and to learn new things [29].

Early language development, rich vocabulary and increased communication capacity have been systematically studied $[24,30]$. It has been found that gifted children from the age of two use general vocabulary and make complex sentences. As gifted children are growing, cognitive changes are big and according to many studies, important developmental differences are observed in the rate of cognitive development when compared with children of typical development [31]. The most significant differences were observed in the increased perceptive ability, logical thinking and conclusion drawing, integration of school learning, early reading, cognitive style and speed of process, creative thinking and creative use of the language [32].

The exceptional comprehension skills are matched with the enhanced linguistic ability. Gifted children understand complex and abstract concepts and relations that are normally taught at bigger ages. According to Bryant [33], the characteristics of children who learn to read at an early age, include: fast and independent learning, general knowledge, thinking ability and problem-solving, increased curiosity, good memory and attention, capability of producing original ideas and rich vocabulary. The combination of natural curiosity and eagerness to learn leads to frequently asking questions and searching for knowledge $[34,35]$. Under the light of speed and logical thinking, it is not surprising that the ability to ask questions, the understanding of cause/effect relation, the concurrent problem solving, perseverance and acuity are characteristics of intelligent children. In general, intellectually gifted students prefer flexible learning styles that go beyond the typical memorization that produce feelings of boredom. Instead they are keen on learning activities in which they are actively engaged and help mobilize on creative learning. Additionally, they tend to learn more quickly and examine deeply a subject compared to their average intelligent peers. Cognitive flexibility, i.e., the ability to adapt prior knowledge to a new type of problem, has been the core of a lot of research. Researchers discovered that this is actually an extremely important element of intellectual and academic giftedness [36]. Data support the notion that gifted children are able to solve problems even from an early age through a new implementation of already acquired knowledge [37].

An analysis of Wechsler's Scale of Intelligence for Children was performed on the profile of 456 students, all of whom had an IQ score of 120 and more [38]. A variation was seen in the profile, with a greater frequency of exceptionally high scoring, greater deviations between verbal and practical quotient and greater dispersion among scores in the subscales. Also, these children scored quite high in subscales that involved a more complex way of thinking (e.g. similarities and patterns with cubes) and moderate in subscales that measure more low-level thinking capacity (coding and memorizing numbers). Papadopoulos and Mutafova [27] analyzed the scores of 60 students aged 5-6 using Wechsler's Intelligence Scales (IQ between 120 to 130). They found that the subjects' scores were remarkably high in the general linguistic indicator and the speed of process indicator.

As for the learning style of these children, the most common feature found in a gifted child is that of great capability of focusing attention and efforts into goals with adequate challenges. According to Silverman [29], young gifted children were found to show early use of metacognitive skills, fast learning, reading and writing, impressive use of numbers and mathematical skills. A basic learning characteristic of a gifted child is the quick interpretation of the cause/effect relation and the ability for independent work on objects that stimulate one's interest.

These characteristics of young gifted children should be recognized by teachers and school psychologists in order to fulfill their needs at an educational and psychological level.

\section{Psycho-pedagogical and Gifted Education Interventions}

National educational systems of Western civilization put the identification of special characteristics of gifted children in a high priority. If gifted children are found at an educational setting that does not take into account their special cognitive and learning abilities, then feelings of frustration, boredom, under-achievement and other 
negative characteristics will emerge, resulting in the need for careful consideration before being exposed to other psychological situations [39].

The integration of gifted students at a typical classroom may be successful if the following conditions are met:

1) Small number of students.

2) Flexible teaching that cultivates autonomy in learning and thinking.

3) Cognitive training methods that promote problem solving in everyday life.

4) Teachers with knowledge and motivation that overcome objective limitations and cultivate creative teaching principles for students with mixed abilities.

The content and the learning process must be consistent with the needs and specific interests of these students [40]. During an examination of children special ability and their problems, researchers such as Slavin et al. [41] suggested alternative ways of education that are implemented in most countries [42-44].

\section{Acceleration}

The acceleration approach has been internationally investigated and the relevant studies have been supportive of its usefulness. Passow [45] states that "the acceleration involves all educational and administrative arrangement that helps the student to progress faster and complete the program in less time or at an earlier than the expected age". Acceleration is a number of practices, including the compacting of the analytical program or grade skipping. The material and assignments are the same, though faster. Compacting enables the student to progress at a faster rate. Students can be accelerated only to a particular cognitive subject, leaving the rest at a normal pace. The usual learning experiences are compacted through acceleration and the child progresses to a higher level [44].

Acceleration can be expressed in a variety of ways: a) early entry to school, kindergarten or elementary school, b) grade skipping or 'double promotion', c) enrollment in accelerated grades, d) enrollment in parallel grades [4].

Acceleration is usually beneficial for gifted and talented students. When are not applied to gifted students, feelings of boredom arising due to lack of learning challenges? Gifted students fail to develop good studying habits or become arrogant because schoolwork requires minimum effort [44].

The main argument of acceleration supporters is that the educational system should not ignore the potential of gifted students by forcing them to follow the slow learning steps of their peers and place them on an educational setting that is below their expectations and potential. Early enrollment to kindergarten allows students to complete the educational procedure at a faster rate, thus saving time from an educational program that will not have new knowledge to offer them [44].

According to Davis and Rimm [12] the early enrollment in kindergarten requires high IQ index, i.e. cognitive abilities, in order to be able to participate in various activities. Important elements are the reading and numbering skills, since it has been observed that many children can read before their school admission. Theoreticians also note that children should have the necessary social and emotional maturity, in order to adapt easily to new environments.
Despite the number of studies that support the benefits of acceleration in the cognitive level and the positive self-appreciation of students as far as their abilities and early development are concerned [46,47], many investigators such as Kulik and Kulik [40] and Cornell [48] discovered a huge research gap. Very few theoreticians have examined with valid scientific methods and appropriate psychological tools the effects of acceleration in the social/emotional adjustment of gifted children.

\section{Enrichment}

The educational approach of enrichment is a rather general term, viewed by the majority of experts as the most positive support of gifted children, as it is being a composite choice and educational activities procedure, which can benefit all the children in the classroom. Schiever and Maker [30] defined enrichment as "... a richer, more diverse educational process, through a modified curriculum ...” Enrichment programs aim at the development of higher cognitive functions and creativity through the development of critical and creative thinking, assimilation of the basic steps of the research process, encouragement to change the rules, cultivation the use of metacognitive and already conquered knowledge and autonomy at work $[30,49]$.

Enrichment programs of a typical program for a few hours a day or week in designated rooms (e.g. library, PC or workshop classrooms), which help children work individually, are divided in pairs or teams with special school or extracurricular activities that do not normally exist in typical programs. The advantages of such an approach are that the activities correspond to the interests and needs of the specific children. Additionally, no differentiation between students is being made. On the other hand, one disadvantage of the enrichment process is the need for more specially trained teachers and infrastructure. Another disadvantage is the possibility of poor program coordination. Enrichment programs focus on individual activities according to the student's interests, with partial supervision.

According to Renzulli [4] the application of enrichment programs includes the following elements:

Type 1: Experiences that do not follow the curriculum and aim at acquainting students to a variety of activities, arts, topics, discussions and hobbies

Type 2: Group educational activities that aim at developing the processes of thought and emotions

Type 3: The student takes the role of a little researcher that has to solve a real problem.

\section{Differentiation}

Differentiation is a procedure of constant adjustment of the curriculum and teaching material in the framework of a typical classroom, in order to provide unique learning opportunities and diverse educational approaches, depending on the readiness, interest and learning profiles of the students. It is an organized and at the same time flexible thinking and action strategy that affects the approach and evaluation of teaching, learning and curriculum, the use of time and the establishment of rules in the classroom. The implementation of differentiation requires alternative teaching methods and aims at the enrichment of productive and creative activities. According to Matsagouras [25], differentiation proves to be a beneficial method not only for gifted children but for all students.

The differentiation of teaching and curriculum satisfies both of their basic needs, i.e., early and accelerated learning adapted to their 
capabilities, and deeper and holistic education. Teaching extends beyond the formal curriculum and allows students to experience a deeper and broad understanding of a concept as well as form crosscurricular connections. In order to be understood by new students the techniques and activities implemented by teachers in the phase of differentiation require a competent teacher who constantly seeks new information that can pass to the demanding 'audience', i.e., the gifted children. The ultimate goal of differentiation is to cultivate the ability of students in terms of understanding and generalizing concepts on their own. As a consequence of differentiation, children could for example be driven to compile a text, a project, an artistic exhibition, etc. Antoniou [46] argues that among the characteristics a teacher must have is his own giftedness in terms of teaching and passing on new knowledge and creativity. Teacher should also stir the needs of gifted children towards appropriate outlets.

\section{Grouping - Individual student groups}

Grouping is another successful technique employed in the education of gifted children. According to Kulik and Kulik [40] and Rogers [20] schools should be able to support a complementary structure. Alternative solutions range from flexible grouping of gifted children, i.e., aiming at accelerating learning and furthering the knowledge, to the creation of special schools for gifted children and the formation of individual groups of students. The advantage of this method is that gifted students under a homogenous group feel accepted and secure enough to develop their potential, while at the same time; egocentric tendencies and behaviors of superiority are avoided. The disadvantage of this method is that the act of grouping could be perceived as discrimination. However, elitism is a problem that may arise from the behavior between students and parents. In Greece, even though the educational system does not allow the creation of schools for gifted children, there are schools for talented students in specific domains, such as music and sports.

An intermediate solution could be the creation of homogenous groups at conventional schools. The advantages of this method is that gifted students learn to cooperate and interact at grade level with students of similar capabilities and also that they are actively engaged in school activities with the rest of the children. However, the implementation of this flexible model in educational systems that are strictly structured may prove to be quite difficult [11].

According to research, gifted children do benefit from special schools, given the fact that they are provided with the opportunity to cultivate their talents and enhance their capabilities for high achievements. Encouraging results from the performance of gifted children at such schools indicates that the existence of special schools could be an appropriate solution that fulfills the gifted student's needs [50].

\section{Conclusion}

The general curriculum cannot meet the special cognitive-learning abilities and socio-emotional needs of gifted students. Gifted students at preschool education and elementary grades are a population with educational needs that regular classrooms cannot often provide because they learn in a different way than compared to non-gifted peers. Gifted education has a prominent role: a) to provide deeper knowledge, perceptual and thinking skills, b) to develop personality and creativity characteristics and c) to enhance relationship skills of gifted students. Therefore, enrichment programmers, acceleration, special schools, special classes, special clubs and groups in school setting, may all be called gifted education intervention [51].
Enrichment has been found to be as one of the most important educational opportunities that are provided for gifted learners. Moreover enrichment programmes can help all the students and not only the gifted population. This method offers in gifted students the opportunity to develop thinking abilities at a higher level of thought and feeling of process; moreover it helps develop creative thinking and in depth studies of a subject. These goals are general commons for all the best and known enrichment models [11,51].

Various research studies have supported the effectiveness of acceleration as an education opportunity for intellectually gifted learners $[44,52]$. Early entry to school may be a priority for some intellectually gifted children, although researchers are divided as for the effectiveness of this curriculum proposal [16,32]. On the other hand, some researchers believe that acceleration may have negative consequences for both students and families [53,54]. Studies have reported evidence that special schools and special classes improve academic achievements and social functioning of gifted students because general classrooms are not the appropriate environment for the development of school accomplishments of gifted students. However, some students do not easily accept being separated from their peers by following a special program. Accelerated students and students enrolled in gifted classes report better perceptions of their peer relations and emotional skills and were also reported to have fewer problems with social behaviour than their non-gifted peers $[49,55]$.

Gifted education intervention should include evidence-based counseling and social-emotional strategies for the improvement of selfconcept, self-esteem, psychological well-being and positive adjustment of gifted students. Contemporary research and clinical studies indicate that counseling approaches for gifted children should employ a preventive developmental enhancement of the students' mental health through creative, interactive activities and positive psychological strategies [5,21]. Furthermore, parents and families play an important role on the development of the gifts and talents of their children. Studies have shown that these gifted education programmes may have a deeper impact on gifted students if parents help children work through these issues.

In conclusion, gifted programmes and activities should meet students' psychological and learning needs within their school and their social environment, and not in isolation from everyday life.

\section{References}

1. Freistas LBL, Shelton TL, Trudge JRH (2003) Conceptions of US and Brazilian early childhood care and education. A historical comparative analysis. International Journal of Behavioural Development. 32: 161-170.

2. Chapparo CJ, Hooper E (2002) When is it work? Perceptions of six year old children. Work 19: 291-302.

3. Borland $\mathrm{JH}$, Wright $\mathrm{L}(2000)$ Identifying and educating poor and underrepresented gifted students. International handbook of giftedness and talent (2nd edn) Oxford, USA.

4. Renzulli JS (2000) Gifted dropouts: The who and the why Joseph S Renzulli. Gifted Child Quarterly 44: 261-271.

5. Schiever S, Maker J (1997) Enrichment and acceleration, Handbook of gifted education (2nd Edn) Allyn and Bacon, Boston.

6. Piirto (2002) Identifying gifted and talented students: Recurring issues and promising solutions. Journal of Applied School Psychology 1: 31-50.

7. Heward W (2008) Exceptional children: An introduction to special education Upper Saddl. River, NJ: Prentice Hall.

8. Tsiamis (2006) Gifted children lives around us. Athens: Grigoris

9. Guilford JP (1967) The nature of human intelligence, New York, McGraw Hill.

10. Marland S (1972) Education of the gifted and talented report to congress 
Citation: Papadopoulos D (2016) Psycho-Pedagogical and Educational Aspects of Gifted Students, Starting from the Preschool Age; How Can Their Needs Be Best Met? J Psychol Abnorm 5: 153. doi: 10.4172/2471-9900.1000153

Washington, DC: US. Government Printing Office.

11. Sternberg RJ (1997) Developing your child's successful intelligence. Teaching for High Potential, 8-10.

12. Davis GA, Rimm SB (2010) Education of the gifted and talented. Needham Heights, MA: Allyn and Bacon, Boston.

13. Gardner H (1983) Frames of mind, Basic Books, New York.

14. Mutafova M (2014) Self-assessment of teachers and team roles of students. Saarbrucken: Lambert Academic Publishing, Germany.

15. National Association for Gifted Children (2010) NAGC pre-K-grade 12 gifted programming standards: A blueprint for quality gifted education programs.

16. Jolly JL (2009) The National Defence Education Act, current STEM initiatives and the gifted. Gifted Child Today 32: 50-53.

17. Silverman $L$ (2000) Counselling the gifted. Denver: Love.

18. Silverman L (1997) The construct of asynchronous development. Peabody Journal of Education 72: 36-58.

19. Piirto J (2007) Talented children and adults: Their development and education, Waco, TX: Prufrock Press.

20. Rogers KB (2001) Re-forming gifted education: Matching the program to the child. Scottsdale, AZ: Great Potential Press.

21. Reis S, Renzulli J (2004) Current research on the social and emotional development of gifted and talented students: Good news and future possibilities. Psychology in the Schools 41: 119-130.

22. Porter L (1999) Gifted young children: A guide for teachers and parents. Buckingham: Open University Press.

23. Feldhusen JF, Jarwan FA (2000) Identification of gifted and talented youth for educational programs. International Handbook of Giftedness and Talent (2nd edn), Oxford: Pergamon, Turkey.

24. Thomaidou $L$ (2008) Children with high intelligence and excellent learning ability. E. Education of Children with high ability learning. Athens: Metexmio.

25. Matsagouras H (2008) Group-collaborative teaching and learning. Athens: Gutenberg.

26. Heller KA, Mönks, FJ, Sternberg RJ, Subotnik RF (2000) International Handbook of Giftedness and Talent (2nd Edn) Oxford: Pergamon, Turkey.

27. Papadopoulos D, Mutafova M (2015) Identification of young gifted children: Issues on assessment and psychological support. Paper Presentation at 9th Conference of Child Psychiatry, University of Athens, Greece.

28. Winner E, von Karoly C (1998) Giftedness and egalitarianism: A zero sum? National Association of Secondary School Principals. NASSP Bulletin 82: 4760.

29. Silverman KL (2002) Characteristics of giftedness scale: A Review of the Literature.

30. Smith CB (1991) Literature for gifted and talented. The Reading Teacher 44: 608- 609.

31. Kitano MK (1985) Ethnography of a preschool for the gifted. What gifted young children actually do? Gifted Child Quarterly 29: 67-71.

32. Harrison C (2004) Giftedness in early childhood: The search for complexity and connection. Roeper Review 26: 78-84.

33. Bryant MS (1989) Challenging gifted learners through children's literature. Gifted Child Today 12: 45-48.

34. Wilkinson SC (1993) WISC-R profiles of children with superior intellectual ability. Gifted Child Quarterly 37: 84-91.

35. Silverman KL (1993) Counseling needs and programs for the gifted, Pergamon Press, New York.

36. Kanevsky $L$ (1990) Pursuing qualitative differences in flexible use of problem solving strategy by young children. Journal for the Education of the gifted 13: 115-140.
37. Terman LM (1926) Genetic studies of genius: Mental and physical traits of a thousand gifted children. Stanford, CA: Stanford University Press.

38. VanTassel-Baska J (2005) Acceleration strategies for teaching gifted children Practical strategies series in gifted education. Waco, Prufrock Press, Texas.

39. Walberg HJ, Tsai S, Weinstein T, Gabriel CL, Rasher, SP, et al. (1981) Childhood traits and environmental conditions of highly eminent adults. Gifted Child Quarterly 25: 103- 107.

40. Kulik, JA, Kulik CC (1984) Effects of accelerated instruction on students Review of Educational Research 54: 409-425.

41. Coleman JL, Cross LT (2001) Being Gifted in School. U.S.A: Prufrock Press Inc.

42. Morelock M, Morrison K (1992) Gifted children have talents too; Multidimensiona programmes for the gifted in early childhood. Melbourne: Hawker Brownlow Education.

43. Scruggs TE, Mastropieri MA (1988) Acquisition and transfer of learning strategies by gifted and non-gifted students. The Journal of Special Education 22: $153-166$

44. Gross UM (2004) Exceptionally gifted children. London: Rou Hedge Falmer Taylor \& Francis Group.

45. Passow HA (1991) Gifted children. Educational Psychology Encyclopedia, Athens: Ellinika Grammata 4101-4109.

46. Antoniou AS (2009) Gifted \& talented students. Athens: Pasxalidis.

47. Davis GA, Rimm SB (2010) Education of the gifted and talented. Needham Heights, MA: Allyn and Bacon, Boston.

48. Cornell DG, Callahan CM, Bassin LE, Ramsay SG (1991) Affective development in accelerated students. In W. T. Southern \& E. D. Jones (Eds.), the academic acceleration of gifted children. New York: Teachers College Press.

49. Robinson NM (2005) in defence of a psychometric approach to the definition of academic giftedness: A conservative view from a diehard liberal. (2nd edn) Cambridge University Press, New York.

50. Davidson JE, Sternberg RJ (1984) the role of insight in intellectual giftedness Gifted Child Quarterly, 28: 58-64.

51. Gross MUM (2004) Exceptionally gifted children. London: Rou Hedge Falmer Taylor \& Francis Group.

52. Richert ES (2003) Excellence with justice in identification and programming USA: Library of Congress.

53. Papadopoulos D, Mutafova M (2016)A School-based psychological intervention for gifted pre-schooler's. Paper Presentation at 38th Annual Conference of International School Psychological Association. University of Amsterdam, Netherlands.

54. Sternberg RJ (1986) A triarchic theory of intellectual giftedness. (2 $2^{\text {nd }}$ Edn) Conceptions of Giftedness, (pp. 223-243) Cambridge University Press, New York.

55. Webb JT, Kleine PA (1993) Assessing gifted and talented children. Testing young children, Austin, Texas. 